\title{
TEKNIK MENYUSUI YANG BENAR PADA IBU PRIMIPARA DI DESA GAYAMAN KECAMATAN MOJOANYAR KABUPATEN MOJOKERTO
}

\author{
Wiwit Sulistyowati
}

\begin{abstract}
ABSTRAK
Menurut UNICEF, cakupan ASI eksklusif enam bulan di Indonesia masih jauh dari rata-rata dunia, yaitu $38 \%$. Menyusui merupakan pemberian makanan kepada bayi yang secara langsung dari payudara ibu sendiri. Walaupun demikian dalam lingkungan kebudayaan kita saat ini melakukan hal yang sifatnya alamiah tidaklah selalu mudah untuk dilakukan oleh para ibu-ibu menyusui. Tujuan dari penelitian ini adalah untuk mengetahui Teknik Menyusui Yang Benar Pada Ibu Primipara Di Desa Gayaman Kecamatan Mojoanyar Kabupaten Mojokerto.

Penelitian ini menggunakan metode analitik dengan pendekatan cross sectional. Variabel yang diteliti adalah pengetahuan ibu primipara tentang menyusui dan teknik menyusui yang benar. Populasi berjumlah 30 ibu primipara dengan sampel sejumlah 30 ibu primipara yang diambil dengan teknik total sampling. Penelitian ini dilakukan pada tanggal 16-17 Juli 2010. Instrumen pengumpulan data menggunakan kuesioner yang telah diuji validitas. Teknik analisa menggunakan spearman's rank dan disajikan dalam bentuk distribusi frekuensi.

Hasil penelitian didapatkan data bahwa paling banyak responden mempunyai pengetahuan kurang tentang teknik menyusui yang benar yaitu sebanyak 12 ibu primipara (40\%) lebih dari 50\% responden melakukan teknik menyusui dengan benar yaitu sebanyak 16 ibu primipara $(53,3 \%)$. Hasil uji spearman's rho dengan derajat kemaknaan 0,05 didapatkan nilai signifikansi 0,006 , sehingga nilai $0,006<0,05$ yang berarti $\mathrm{H}_{0}$ ditolak dan ada hubungan antara pengetahuan ibu primipara dengan teknik menyusui yang benar Di Desa Gayaman Kecamatan Mojoanyar Kabupaten Mojokerto, dengan nilai korelasi spearman's rho 0,491 yang termasuk dalam kategori cukup erat.

Banyaknya responden yang salah dalam melakukan teknik menyusui selain dikarenakan kurangnya pengetahuan juga banyak dipengaruhi oleh faktor usia, pendidikan, pekerjaan ibu primipara dalam melakukan laktasi.

Simpulan dari penelitian ini adalah terdapat hubungan antara pengetahuan ibu primipara dengan teknik menyusui yang benar. Petugas kesehatan harus berperan aktif untuk senantiasa memberikan bimbingan, arahan, yang berupa penyuluhan kesehatan kepada masyarakat melalui kegiatan posyandu seperti dengan menggalakkan program teknik menyusui yang benar secara rutin dan berkala
\end{abstract}

Kata Kunci : pengetahuan, ibu primipara, teknik menyusui yang benar

\section{A. PENDAHULUAN.}

Menyusui merupakan pemberian makanan kepada bayi yang secara langsung dari payudara ibu sendiri. Menyusui adalah proses alamiah, dimana berjuta-juta ibu melahirkan diseluruh dunia berhasil menyusui bayinya tanpa pernah membaca buku tentang pemberian ASI. Walaupun demikian dalam lingkungan kebudayaan kita saat ini melakukan hal yang sifatnya alamiah tidaklah selalu mudah untuk dilakukan oleh para ibu-ibu menyusui. Menyusui merupakan cara pemberian makan yang diberikan secara langsung oleh ibu kepada anaknya, namun seringkali ibu menyusui kurang memahami dan kurang mendapatkan informasi, bahkan sering kali ibu-ibu mendapatkan suatu informasi yang salah tentang manfaat ASI ekslusif itu sendiri, tentang bagaimana cara menyusui ataupun langka-langkah menyusui yang benar kepada bayinya, dan kurangnya informasi yang diberikan tentang dampak apabila Asi esklusif itu tidak diberikan dan apa yang harus dilakukan bila timbul kesukaran dalam menyusui secara ekslusif kepada bayinya (Utami Roesli, 2000).

WHO, British Nutrition Foundation, ESPGAN (European Society for Pediatric Gastroenterology and Nutrition), WHO (World Health Organization) dan FAO (Food 
Agriculture Organization) merekomendasikan pemberian ASI selama enam bulan pertama setelah kelahiran. Selama itu bayi tidak perlu mendapatkan makanan dan minuman apa pun selain ASI (Surjadi, 2008).

Hasil SDKI 2007 menunjukkan penurunan jumlah bayi yang mendapatkan ASI eksklusif hingga 7,2\%. Pada saat yang sama, jumlah bayi di bawah enam bulan yang diberi susu formula meningkat dari $16,7 \%$ pada 2002 menjadi 27,9\% pada 2007. UNICEF menyimpulkan, cakupan ASI eksklusif enam bulan di Indonesia masih jauh dari rata-rata dunia, yaitu 38\%. Dari survei yang dilaksanakan pada tahun 2007 oleh Nutrition \& Health Surveillance System (NSS) yang berkerjasama dengan Balitbangkes dan Helen Keller International di 4 perkotaan (Jakarta, Surabaya, Semarang, Makasar) dan 8 perdesaan (Sumbar, Lampung, Banten, Jabar, Jateng, Jatim, NTB, Sulsel), menunjukan bahwa cakupan ASI eksklusif 4-5 bulan di perkotaan antara 4\%-12\%, sedangkan dipedesaan 4\%-25\%. Pencapaian ASI eksklusif 5-6 bulan di perkotaan berkisar antara hanya 1\%-13\% sedangkan di pedesaan 2\%-13\%. Sedangkan untuk wilayah Mojokerto cakupan pada tahun 2008 sebanyak 70\%, sedangkan target pada 2010 sebanyak $90 \%$ (DinkesJatim, 2010). Permasalahan yang utama rendahnya angka cakupan ASI ini adalah karena faktor sosial budaya, kesadaran akan pentingnya ASI, pelayanan kesehatan dan petugas kesehatan yang belum sepenuhnya mendukung serta gencarnya promosi susu (Arief, 2009).

Kurangnya informasi dan tidak adanya tenaga terlatih menunjukkan bahwa kesadaran pemberian ASI hanya akan tumbuh dengan topangan informasi yang baik dan adanya dukungan dari masyarakat. gencarnya promosi susu formula benar-benar merubah paradigma masyarakat terhadap ASInya, dan menurunkan kepercayaan diri ibu bahwa ASI adalah sumber nutrisi terbaik dan satu-satunya nutrisi ideal bagi bayi (Sugianto,2008).

Kecenderungan ibu primipara mempunyai pengetahuan rendah dimungkinkan karena melahirkan seorang anak merupakan pengalaman baru, sehingga dapat menjadi stressor yang pada akhirnya dapat menimbulkan krisis. Untuk itu mereka membutuhkan pemahaman atau pengetahuan dan ketrampilan yang harus diperoleh melalui praktek tentang bagaimana cara menyusui yang benar (WHO, 2002; 37). Pengetahuan tentang teknik menyusui harus dikuasai dengan benar demi kelancaran pemberian ASI Eksklusif. Teknik tersebut meliputi posisi dan perlekatan yang benar, langkah-langkah menyusui, cara pengamatan teknik menyusui dan lama frekuensi menyusui. Yang paling penting dari teknik menyusui setelah tidak terdapat kendala dari ibu maupun bayi adalah lama dan frekuensi yang tidak dijadwal sehingga tindakan menyusui bayi dilakukan di setiap saat bayi membutuhkan, karena bayi akan menentukan sendiri kebutuhannya. Ibu harus menyusui bayinya bila bayi menangis bukan karena sebab lain (kencing, kepanasan/kedinginan atau sekedar ingin didekap) atau ibu sudah merasa perlu menyusui bayinya (Pernisa, 2004, dikutip Creasoft, 2008).

Teknik menyusui yang tidak dikuasai oleh ibu maka akan berdampak pada ibu dan bayi itu sendiri. Dampak pada ibu bisa berupa mastitis, payudara bergumpal, puting sakit, sedangkan pada bayi dapat dipastikan, bayi tidak akan mau menyusu yang berakibat bayi tidak akan mendapat ASI eksklusif (Idrus, 2009).

Pemberian Air Susu Ibu (ASI) pada bayi sejak awal sangat penting dilakukan. Oleh karena itu sudah menjadi tugas tenaga kesehatan khususnya bidan untuk dapat memberikan pendidikan kesehatan baik itu melalui konseling, penyuluhan, media informasi seperti liflet, lembar balik dan sebagainya. Pemberian HE sebaiknya diberikan pada waktu ibu masih hamil sehingga ibu mempunyai motivasi untuk memberikan ASI eksklusif sejak awal.

B. TINJAUAN PUSTAKA.

1. Konsep Dasar Pengetahuan

a. Definisi

Pengetahuan (knowledge) adalah kebiasaan, keahlian / kepakaran, keterampilan, pemahaman, atau pengertian yang diperoleh dari pengalaman, latihan atau melalui proses belajar (Pratomo, 2005).

Pengetahuan adalah informasi atau maklumat yang diketahui atau disadari oleh seseorang. Pengetahuan termasuk, tetapi tidak dibatasi pada deskripsi, hipotesis, konsep. 
teori, prinsip dan prosedur yang secara Probabilitas Bayesian adalah benar atau berguna Dalam pengertian lain, pengetahuan adalah pelbagai gejala yang ditemui dan diperoleh manusia melalui pengamatan akal.Pengetahuan muncul ketika seseorang menggunakan akal budinya untuk mengenali benda atau kejadian tertentu yang belum pernah dilihat atau dirasakan sebelumnya. Misalnya ketika seseorang mencicipi masakan yang baru dikenalnya, ia akan mendapatkan pengetahuan tentang bentuk, rasa, dan aroma masakan tersebut (Wikipedia Indonesia, 2010).

Pengetahuan adalah hasil dan tahu, dan ini terjadi setelah orang melakukan pengindraan terhadap suatu objek tertentu. Pengetahuan atau kognitif merupakan domain yang sangat penting untuk terbentuknya tindakan seseorang (Notoatmodjo, 2003).

b. Tingkat pengetahuan

Menurut Notoatmodjo (2003) pengetahuan yang tercakup dalam domain kognitif mempunyai 6 tingkatan yaitu:

1) Tahu (know)

Tahu di artikan sebagai mengingat suatu materi yang telah di pelajari sebelumnya. Termasuk dalam pengetahuan tingkat ini adalah mengingat kembali (recall) sesuatu yang spesifik dan seluruh bahan yang di pelajari atau rangsangan yang di terima, ini adalah tingkat pengetahuan yang paling rendah, kata kerja untuk mengukur dengan menyebutkan, menguraikan, mendefinisikan, menyatakan dan sebagainya

2) Memahami (comprehension)

Memahami di artikan sebagai suatu kemampuan untuk menjelaskan secara benar tentang objek yang di ketahui, dan dapat menginterprestasikan materi tersebut secara benar. Orang yang telah paham terhadap objek atau materi harus dapat menjelaskan, menyebutkan contoh, menyimpulkan, meramalkan, dan sebagainya terhadap objek yang di pelajari.

3) Aplikasi (application)

Aplikasi diartikan sebagai kemampuan untuk menggunakan materi yang telah di pelajari pada situasi atau kondisi real (sebenamya). Aplikasi di sini dapat di artikan sebagai aplikasi atau penggunaan hukum, rumus, metode, prinsip, dan sebagainya dalam konteks atau situasi yang lain.

4) Analisis (analysis)

Analisis adalah suatu kemampuan untuk menjabarkan materi atau suatu objek ke dalam komponen - komponen tetapi masih di dalam satu struktur organisasi,. kemampuan analisis ini dapat di lihat dan penggunaan kata kerja, seperti menggambarkan, membedakan, memisahkan, dan sebagainya.

5) Sintesis (synthesis)

Sintesis adalah suatu kemampuan untuk menyusun formula baru dan formulasi yang ada. Menunjuk kepada suatu kemampuan untuk meletakkan atau menghubungkan bagian - bagian di dalam suatu bentuk keseluruhan yang baru misalnya dapat menyusun, merencanakan, meringkas, dan sebagainya terhadap suatu teori atau rumusan yang telah ada.

6) Evaluasi (evaluation)

Evaluasi berkaitan dengan kemampuan untuk melakukan justifikasi atau penilaian terhadap suatu materi atau objek, penilaian di dasarkan pada suatu kriteria yang di tentukan sendiri atau menggunakan kriteria yang sudah ada.

c. Cara Memperoleh Pengetahuan

Menurut Notoatmodjo (2005), terdapat 2 cara untuk memperoleh pengetahuan yaitu:

1) Cara tradisional

Cara tradisional di pakai orang untuk memperoleh kebenaran pengetahuan sebelum di temukannya metode ilmiah, cara penemuan pengetahuan pada periode ini antara lain: 
a) Cara coba - salah (Trial and error)

Cara ini telah di pakai orang sebelum adanya kebudayaan, bahkan mungkin sebelum adanya peradapan, cara coba — salah ini di lakukan dengan menggunakan kemungkinan dalam memecahkan masalah, dan apabila kemungkinan tersebut berhasil, di coba kemungkinan yang lain.

b) Kekuasaan (otoritas)

Para pemegang otoritas, baik pemimpin pemerintahan, tokoh agama, maupun ahli ilmu pengetahuan pada prinsipnya mempunyai mekanisme sama di dalam pengetahuan. Prinsip ini adalah orang lain menerima pendapat yang di kemukakan orang yang mempunyai otoritas, tanpa lebih dulu menguji atau membuktikan kebenaranya, baik berdasar fakta empiris maupun penalaran sendiri.

c) Berdasarkan pengalaman pribadi

Pengetahuan adalah guru yang baik pepatah ini mengandung maksud bahwa pengalaman itu merupakan suatu cara untuk memperoleh kebenaran pengetahuan.

d) Melalui jalan pikiran

Sejalan dengan perkembangan kebudayaan umat manusia pun ikut berkembang. Dan sini manusia telah mampu menggunakan penalaranya dalam memperoleh kebenaran pengetahuan, manusia telah menggunakan jalan pikiranya, baik melalui induksi (proses penarikan kesimpulan ) maupun deduksi (pembuatan kesimpulan).

2) Cara modern

Cara baru atau modem dalam memperoleh pengetahuan pada dewasa ini lebih logis dan ilmiah, cara ini di sebut" metode penelitian ilmiah"

\section{d. Jenis Pengetahuan}

Menurut Pratono (2005) ada dua jenis pengetahuan, yaitu pengetahuan eksplisit dan pengetahuan tacit. Pengetahuan eksplisit dapat diungkapkan dengan kata-kata dan angka, disebarkan dalam bentuk data, spesifikasi, dan buku petunjuk, sedangkan pengetahuan tacit sifatnya sangat personal yang sulit diformulasikan sehingga sulit dikomunikasikan kepada orang lain.

1) Explicit Knowledge. Bentuk pengetahuan yang sudah terdokumentasi/terformalisasi, mudah disimpan, diperbanyak, disebarluaskan dan dipelajari. Contoh: manual, buku, laporan, dokumen, surat dan sebagainya.

2) Tacit Knowledge. Bentuk pengetahuan yang masih tersimpan dalam pikiran manusia. Misalnya gagasan, persepsi, cara berpikir, wawasan, keahlian/kemahiran, dan sebagainya.

\section{e. Faktor yang mempengaruhi pengetahuan}

Menurut Meliono yang dikutip di Wikipedia Indonesia (2010) pengetahuan seseorang dipengaruhi oleh beberapa faktor, diantaranya:

1) Pendidikan

Pendidikan" adalah sebuah proses pengubahan sikap dan tata laku seseorang atau kelompok dan juga usaha mendewasakan manusia melalui upaya pengajaran dan pelatihan, maka jelas dapat kita kerucutkan sebuah visi pendidikan yaitu mencerdaskan manusia.

2) Media

Media yang secara khusus didesain untuk mencapai masyarakat yang sangat luas. Jadi contoh dari media massa ini adalah televisi, radio, koran, dan majalah.

3) Keterpaparan informasi

Pengertian informasi menurut Oxfoord English Dictionary, adalah "that of which one is apprised or told: intelligence, news". Kamus lain menyatakan bahwa informasi adalah sesuatu yang dapat diketahui. Namun ada pula yang menekankan informasi sebagai transfer pengetahuan. Selain itu istilah informasi juga memiliki arti yang lain sebagaimana diartikan oleh RUU teknologi informasi yang mengartikannya sebagai 
suatu teknik untuk mengumpulkan, menyiapkan, menyimpan, memanipulasi, mengumumkan, menganalisa, dan menyebarkan informasi dengan tujuan tertentu. Sedangkan informasi sendiri mencakup data, teks, image, suara, kode, program komputer, databases .

Sedangkan menurut Erfandi (2009) yang mengutip dari beberapa sumber, ada beberapa faktor yang mempengaruhi pengetahuan seseorang, yaitu :

1) Pendidikan.

Pendidikan adalah suatu usaha untuk mengembangkan kepribadian dan kemampuan di dalam dan di luar sekolah dan berlangsung seumur hidup. Pendidikan mempengaruhi proses belajar, makin tinggi pendidikan seeorang makin mudah orang tersebut untuk menerima informasi. Dengan pendidikan tinggi maka seseorang akan cenderung untuk mendapatkan informasi, baik dari orang lain maupun dari media massa. Semakin banyak

2) Mass media/informasi

Informasi yang diperoleh baik dari pendidikan formal maupun non formal dapat memberikan pengaruh jangka pendek (immediate impact) sehingga menghasilkan perubahan atau peningkatan pengetahuan. Majunya teknologi akan tersedia bermacam-macam media massa yang dapat mempengaruhi pengetahuan masyarakat tentang inovasi baru. Sebagai sarana komunikasi, berbagai bentuk media massa seperti televisi, radio, surat kabar, majalah, dan lain-lain mempunyai pengaruh besar terhadap pembentukan opini dan kepercayaan orang.

3) Sosial budaya dan ekonomi.

Kebiasaan dan tradisi yang dilakukan orang-orang tanpa melalui penalaran apakah yang dilakukan baik atau buruk. Dengan demikian seseorang akan bertambah pengetahuannya walaupun tidak melakukan. Status ekonomi seseorang juga akan menentukan tersedianya suatu fasilitas yang diperlukan untuk kegiatan tertentu, sehingga status sosial ekonomi ini akan mempengaruhi pengetahuan seseorang.

4) Lingkungan.

Lingkungan adalah segala sesuatu yang ada di sekitar individu, baik lingkungan fisik, biologis, maupun sosial. Lingkungan berpengaruh terhadap proses masuknya pengetahuan ke dalam individu yang berada dalam lingkungan tersebut. Hal ini terjadi karena adanya interaksi timbal balik ataupun tidak yang akan direspon sebagai pengetahuan oleh setiap individu.

5) Pengalaman.

Pengalaman sebagai sumber pengetahuan adalah suatu cara untuk memperoleh kebenaran pengetahuan dengan cara mengulang kembali pengetahuan yang diperoleh dalam memecahkan masalah yang dihadapi masa lalu. Pengalaman belajar dalam bekerja yang dikembangkan memberikan pengetahuan dan keterampilan professional serta pengalaman belajar selama bekerja akan dapat mengembangkan kemampuan mengambil keputusan yang merupakan manifestasi dari keterpaduan menalar secara ilmiah dan etik yang bertolak dari masalah nyata dalam bidang kerjanya.

6) Usia.

Usia mempengaruhi terhadap daya tangkap dan pola pikir seseorang. Semakin bertambah usia akan semakin berkembang pula daya tangkap dan pola pikirnya, sehingga pengetahuan yang diperolehnya semakin membaik. Dua sikap tradisional mengenai jalannya perkembangan selama hidup.

f. Pengukuran Pengetahuan

Menurut Erfandi (2009) Pengukuran pengetahuan dapat dilakukan dengan memberikan seperangkat alat tes / kuesioner tentang object pengetahuan yang mau diukur, selanjutnya dilakukan penilaian dimana setiap jawaban benar dari masing-masing pertanyaan diberi nilai 1 dan jika salah diberi nilai 0 . 
Penilaian dilakukan dengan cara membandingkan jumlah skor jawaban dengan skor yang diharapkan (tertinggi) kemudian dikalikan 100\% dan hasilnya berupa prosentase dengan rumus yang digunakan sebagai berikut:

$$
N=\frac{S p}{S m} \times 100 \%
$$

Keterangan :

$\mathrm{N} \quad=$ Nilai pengetahuan

$\mathrm{Sp} \quad=$ Skor yang didapat

$\mathrm{Sm}=$ Skor tertinggi maksimum

Selanjutnya prosentase jawaban diinterpretasikan dalam kalimat kualitatif dengan acuan sebagai berikut :
1) Baik
$:$ Nilai $=76-100 \%$
2) Cukup
$:$ Nilai $=56-75 \%$
3) Kurang
: Nilai $=40-55 \%$
4) Tidak baik : Nilai $<40 \%$
Erfandi (2009)

\section{Konsep Dasar Menyusui}

\section{a. Definisi}

Menyusui adalah proses pemberian susu kepada bayi atau anak kecil dengan air susu ibu (ASI) dari payudara ibu. Bayi menggunakan refleks menghisap untuk mendapatkan dan menelan susu (Wikipedia, 2010). Menyusui adalah proses memberikan makanan pada bayi dengan menggunakan air susu ibu langsung dari payudara ibu. Jadi yang dimaksud disini bukan memberikan susu dengan menggunakan botol atau sarana lainnya (Blogdokter, 2008)

b. Anjuran Inisiasi Menyusui Dini

Menurut Marimbi (2010) beberapa alasan ibu dianjurkan menyusui bayinya segera setelah lahir sebagai berikut:

1) Menyusui bayi akan memberikan kepuasan dan ketenangan pada ibu, beberapa ahli menyatakan bahwa menyusui akan memberikan rasa bangga pada ibu, karena ia telah dapat memberikan kehidupan pada bayinya.

2) Hisapan bayi akan mempercepat proses kembalinya uterus keukuran yang normal

3) Hisapan bayi akan memperlancar produksi ASI

4) Penelitian membuktikan bahwa bayi yang disusui segera setelah lahir lebih jarang menderita penyakit infeksi dan gizi bayi pada tahun pertama jauh lebih baik dibanding dengan bayi yang terlambat diberi ASI.

c. Hal yang perlu dipertimbangkan dalam menentukan frekuensi pemberian ASI

Menurut Marimbi (2010) adapun alasan penggunaan jarak waktu pemberian ASI, ada beberapa hal yang perlu dipertimbangkan dalam menentukan frekuensi pemberian ASI:

1) Jarak waktu menyusui yang terlalu dekat sering menyebabkan bayi tidak mampu menghabiskan ASI yang ada dalam payudara ibu.

2) Payudara yang tidak habis/kosong terhisap akan melemahkan rangsangan terhadap selsel yang menghasilkan ASI, sehingga produksi ASI akan cepat menurun.

3) Seorang ahli kesehatan anak "Share" mengemukakan pendapatnya bahwa anak yang makannya sedikit-sedikit akan mengakibatkan hilangnya nafsu makan karena kadar gula dalam darah anak selalu tinggi, keadaan ini akan mengurangi nafsu makan anak secara keseluruhan.

\section{d. Teknik Menyusui}

Menurut Perinasia yang dikutip Creasoft (2008) yang mengutip teknik menyusui dapat dilihat sebagai berikut :

1) Posisi dan perlekatan menyusui

Terdapat berbagai macam posisi menyusui. Cara menyususi yang tergolong biasa dilakukan adalah dengan duduk, berdiri atau berbaring 
2) Langkah-langkah menyusui yang benar

Bayi diletakkan menghadap ke ibu dengan posisi sanggah seluruh tubuh bayi, jangan hanya leher dan bahunya saja, kepala dan tubuh bayi lurus, hadapkan bayi ke dada ibu, sehingga hidung bayi berhadapan dengan puting susu, dekatkan badan bayi ke badan ibu, menyetuh bibir bayi ke puting susunya dan menunggu sampai mulut bayi terbuka lebar

\section{e. Cara pengamatan teknik menyusui yang benar}

Menyusui dengan teknik yang tidak benar dapat mengakibatkan puting susu menjadi lecet, ASI tidak keluar optimal sehingga mempengaruhi produksi ASI selanjutnya atau bayi enggan menyusu. Apabila bayi telah menyusui dengan benar maka akan memperlihatkan tanda-tanda sebagai berikut :

1) Bayi tampak tenang.

2) Badan bayi menempel pada perut ibu.

3) Mulut bayi terbuka lebar.

4) Dagu bayi menempel pada payudara ibu.

5) Sebagian areola masuk kedalam mulut bayi, areola bawah lebih banyak yang masuk.

6) Bayi nampak menghisap kuat dengan irama perlahan.

7) Puting susu tidak terasa nyeri.

8) Telinga dan lengan bayi terletak pada satu garis lurus.

9) Kepala bayi agak menengadah.

f. Tips Untuk menyusui

1) Berikan ASI Sesuai Kebutuhan.

2) Cari Posisi yang Nyaman. Untuk menghindari nyeri di punggung bagian bawah, jangan membungkuk saat memberikan AS1. Bawa bayi mendekati payudara. Duduk di kursi yang menyediakan sandaran yang nyaman bagi punggung. Pilihan lain adalah dengan berbaring menyamping atau berbaring menyamping dan bayi menghadap ke ibu.

3) Gunakanlah Baju yang Lebar. Biasanya para ibu memilih menggunakan baju yang lebar dengan kancing di bagian depan. ini akan mempermudah jika saat menyusui tiba.

4) Biarkan Bayi Mencari Posisinya sendiri. Saat menyusu adalah saat makan bagi bayi. Diajuga akan membutuhkan kenyamanan. Bayi mungkin akan berhenti sebentar saat menyusu, melihat ibunya dan sekeliling ruangan. ini sering terjadi dan hanyalah istirahat sebentar. Tidak ada masalah dengan proses rnenyusu itu sendiri.

5) Hindari Ketergesaan dalam Menyusui. Jangan tergesa-gesa ketika sedang menyusui. Gunakan waktu ini untuk menjalin ikatan di antara ibu dengan anak.

6) Tawarkan Kedua-duanya. Gunakan payudara yang berbeda saat memulai menyusui. Susui bayi hingga payudara pertama terasa lembut. Apabila bayi bersendawa, coba tawarkan payudara yang kedua.

7) Ikuti petunjuk bayi untuk mengetahui kapan saatnya berhenti. Kebanyakan bayi akan berhenti menghisap ASI bila sudah kenyang. Kadang bayi langsung tertidur atau melepaskannya begitu saja

8) Biasakan Puting. Puting mungkin akan terasa sedikit teriritasi pada beberapa minggu pertama. Memang tidak nyaman, namun ini sangat normal dan akan terbiasa dengan sendirinya.

9) Jangan Merokok ataupun Meminum Alkohol. Sangat penting untuk menghindari asap rokok, baik sebagai perokok aktif ataupun perokok pasif. Dan hindari mengkonsumsi minuman beralkohol karena kandungan alkohol dapat diteruskan pada bayi melalui ASI. Keduanya sangat tidak baik bagi kesehatan ibu dan bayinya. Weni (2009)

\section{Konsep Dasar ibu Paritas}

\section{a. Pengertian}

Pengertian Para adalah seorang wanita yang pernah melahirkan bayi yang dapat hidup (viabel) (Wiknjosastro,2002). Paritas adalah keadaan pada wanita yang telah 
melahirkan janin yang beratnya 500 gram atau lebih, mati atau hidup dan apabila berat badan tidak diketahui maka dipakai batas umur gestasi 22 minggu terhitung dari hari pertama haid terakhir yang normal (UNPAD, 1998, dikutip oleh Nikilah, 2009).

Paritas ibu yang bersangkutan mempengaruhi morbiditas dan mortalitas ibu dan anak. Risiko terhadap ibu dan anak pada kelahiran bayi pertama cukup tinggi,akan tetapi risiko ini tidak dapat di hindari. Kemudian risiko itu menuru pada paritas kedua dan ketiga serta meningkat lagi pada paritas keempat dan seterusnya (Mochamad, 2000; Cahyono, 2000, dikutip oleh Nikilah, 2009).

b. Macam-macam Paritas

1) Nullipara Seorang wanita yang belum pernah melahirkan bayi yang viable untuk pertama kali

2) Primipara Wanita yang telah melahirkan bayi yang_iable untuk pertama kalinya

3) Multipara (pleuripara) Seorang wanita yang telah melahirkan bayi yang sudah _iable beberapa kali, yaitu 2-4 kali

4) Grandemultipara Seorang wanita yang telah melahirkan bayi yang sudah _iable lima kali atau lebih.

5) Great grandemultipara Seorang wanita yang telah melahirkan bayi yang sudah _iable 10 kali atau lebih. (Nikilah, 2009)

\section{Kerangka Konseptual.}

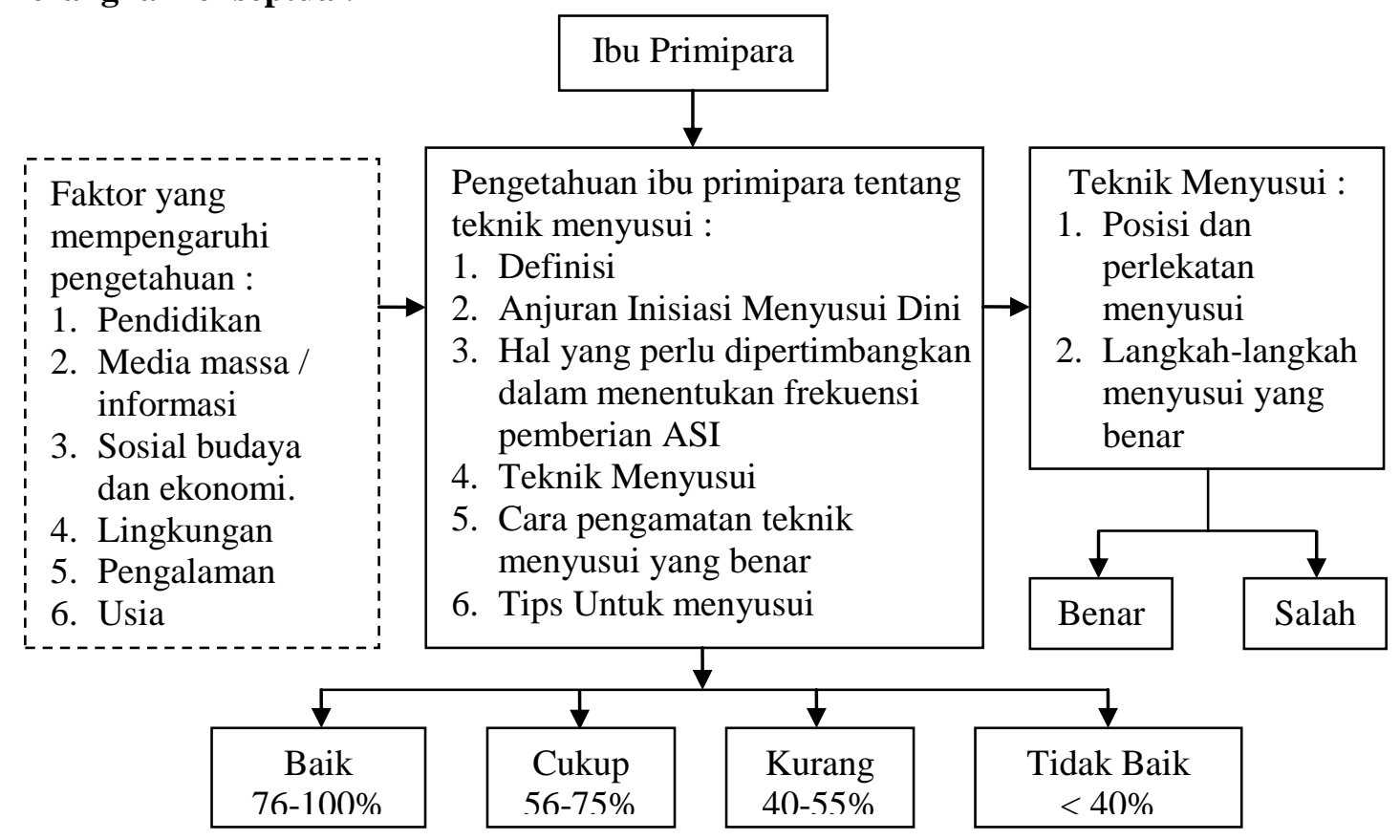

Sumber : Modifikasi Perinasia yang dikutip Creasoft (2008) dan Erfandi (2009)

Keterangan :

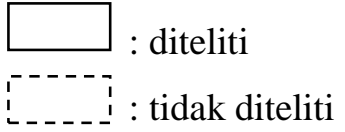

Gambar 16. Kerangka Konseptual Teknik Menyusui Yang Benar Pada Ibu Primipara Di Desa Gayaman Kecamatan Mojoanyar Kabupaten Mojokerto 


\section{METODE PENELITIAN.}

1. Desain Penelitian.

Peneliti menggunakan metode analitik karena bertujuan menganalisa, menjelaskan suatu hubungan, menguji berdasarkan teori yang ada dan menggunakan pendekatan Cross Sectional yaitu jenis penelitian yang menekankan waktu pengukuran atau observasi data variabel independen dan dependen dinilai secara simultan pada suatu saat dan tidak ada tindak lanjut (Nursalam, $2008: 83$ ).

\section{KERANGKA KERJA}

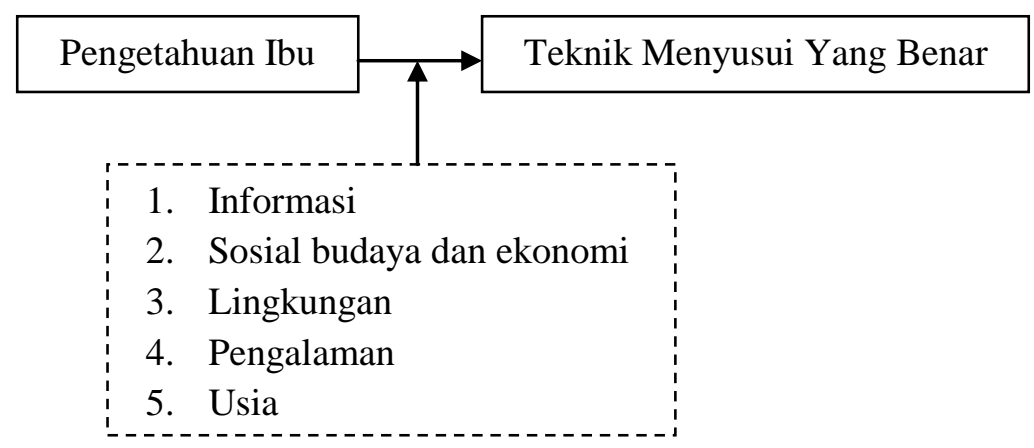

\section{Gambar 17. Kerangka Kerja Teknik Menyusui Yang Benar Pada Ibu Primipara Di Desa Gayaman Kecamatan Mojoanyar Kabupaten Mojokerto}

\section{Hipotesis.}

Hipotesis adalah suatu pernyataan yang masih lemah dan membutuhkan pembuktian menegaskan apakah hipoteisis tersebut dapat diterima atau harus ditolak berdasarkan fakta atau data empiris yang telah dikumpulkan dalam penelitian.

$\mathrm{H}_{1}$ : Ada hubungan pengetahuan ibu primipara dengan teknik menyusui yang benar di Desa Gayaman Kecamatan Mojoanyar Kabupaten Mojokerto.

Ho : Tidak ada hubungan pengetahuan ibu primipara dengan teknik menyusui yang benar di Desa Gayaman Kecamatan Mojoanyar Kabupaten Mojokerto.

3. Populasi, Sampel, Variabel, Instrumen Penelitian, dan Definisi Operaisonal.

Populasi pada penelitian ini adalah seluruh ibu menyusui di Desa Gayaman Kecamatan Mojoanyar Kabupaten Mojokerto pada bulan Juli 2010 sebanyak 30 ibu primipara menyusui dengan sampel yang digunakan adalah ibu menyusui di Desa Gayaman Kecamatan Mojoanyar Kabupaten Mojokerto tahun 2010 sebanyak 30 ibu primipara menyusui.

Teknik sampling yang digunakan oleh peneliti adalah Non probability Sampling dengan sampling jenuh yaitu cara mengambil semua anggota populasi menjadi sampel (Hidayat, 2009).

Variabel independen yang digunakan dalam penelitian ini adalah pengetahuan ibu primipara tentang teknik menyusui, sedangkan variabel dependennya yaitu teknik menyusui yang benar.

Instrumen penelitian ini menggunakan :

a. Pengetahuan

Lembar kuesioner untuk variabel pengetahuan dengan tipe kuesioner tertutup yang sudah diuji validitas dan reliabilitasnya untuk variabel.

1) Uji validitas

Uji validitas instrumen/kuesioner dilakukan pada 10 responden dan hasilnya dihitung pada $\alpha=0,05$ dengan menggunakan rumus person products moment: 


$$
r=\frac{n\left(\sum X Y\right)-\left(\sum X\right)\left(\sum Y\right)}{\sqrt{\left[n \sum X^{2}-\left(\sum X\right)^{2}\right]\left[n \sum Y^{2}-\left(\sum Y\right)^{2}\right]}}
$$

Keterangan:

$\begin{array}{ll}\mathrm{r} & \text { : koefisien korelasi } \\ \sum_{\mathrm{n}} \mathrm{X} & \text { : jumlah skor item } \\ \mathrm{n} & \text { : jumlah skor total item } \\ & \text { : jumlah responden }\end{array}$

Kemudian menghitung nilai uji $\mathrm{T}$ dengan rumus:

$$
\mathrm{t}_{\text {hit }}=\frac{r \sqrt{(n-2)}}{\sqrt{1-r^{2}}}
$$

Keterangan:

$\mathrm{r}$ : koefisien korelasi

$\mathrm{n}$ : jumlah responden, (n-2=dk, derajat kebebasan)

Jika $t_{\text {hit }}>t_{\text {tabel }}$ berarti instrumen valid demikian sebaliknya jika $t_{\text {hit }}<t_{\text {tabel }}$ berarti instrumen tidak valid yang tentunya tidak dapat digunakan dan dapat diperbaiki/ dihilangkan (Hidayat, 2007).

2) Uji reliabilitas

Reliabilitas data diukur dengan teknik belah dua atau rumus spearman Brown:

$$
r_{11}=\frac{2 \cdot r b}{1+r b}
$$

\section{Keterangan:}

$\mathrm{r}_{11} \quad$ : koefisien reliabitas seluruh item

$\mathrm{r}_{\mathrm{b}} \quad$ : koefisien products moment antar belahan

Analisis keputusan, apalagi $r_{11}>r_{\text {tabel }}$ berarti reliabel dan apabila $r_{11}<r_{\text {tabel }}$ tidak reliabel yang di hitung pada derajat kebebasan $\mathrm{dk}=\mathrm{n}-2$ dan $\alpha=0,05$. (Hidayat, 2007)

b. Teknik Menyusui

Menggunakan lembar observasi. Peneliti menyusun lembar observasi berbentuk chek list untuk memudahkan observasi.

\begin{tabular}{|c|c|c|c|}
\hline Variabel & Definisi Operasional & Kriteria & Skala \\
\hline $\begin{array}{l}\text { Independen : } \\
\text { Pengetahuan ibu } \\
\text { primipara tentang } \\
\text { menyusui }\end{array}$ & $\begin{array}{l}\text { Segala sesuatu yang diketahui } \\
\text { ibu primipara tentang teknik } \\
\text { menyusui, meliputi : } \\
\text { 1. Definisi } \\
\text { 2. Anjuran Inisiasi Menyusui } \\
\text { Dini } \\
\text { 3. Hal yang perlu } \\
\text { dipertimbangkan dalam } \\
\text { menentukan frekuensi } \\
\text { pemberian ASI } \\
\text { 4. Teknik Menyusui } \\
\text { 5. Cara pengamatan teknik } \\
\text { menyusui yang benar } \\
\text { 6. Tips Untuk menyusui } \\
\text { Alat ukur menggunakan } \\
\text { kuesioner }\end{array}$ & $\begin{array}{l}\text { 1. Baik : Nilai }=76-100 \% \\
\text { 2. Cukup : Nilai }=60-75 \% \\
\text { 3. Kurang : Nilai }=<60 \% \\
\text { Arikunto }(2006)\end{array}$ & Ordinal \\
\hline
\end{tabular}

Tabel 38. Definisi Operasional Teknik Menyusui Yang Benar Pada Ibu Primipara Di Desa Gayaman Kecamatan Mojoanyar Kabupaten Mojokerto 


\begin{tabular}{|c|c|c|c|}
\hline Variabel & Definisi Operasional & Kriteria & Skala \\
\hline $\begin{array}{l}\text { Dependen : } \\
\text { Teknik menyusui } \\
\text { yang benar }\end{array}$ & $\begin{array}{l}\text { Kemampuan ibu untuk } \\
\text { melakukan teknik menyusui } \\
\text { dengan benar : } \\
\text { a. Posisi dan perlekatan } \\
\text { menyusui } \\
\text { b. Langkah-langkah menyusui } \\
\quad \text { yang benar } \\
\text { Alat Ukur Mengunakan check } \\
\text { list }\end{array}$ & 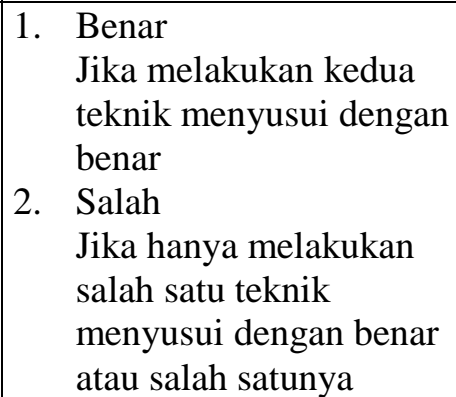 & Nominal \\
\hline
\end{tabular}

\section{Teknik Analisis Data.}

\section{a. Analisis Univariat}

1) Pengetahuan ibu tentang menyusui

Setiap jawaban benar dari masing-masing pertanyaan diberi nilai 1 dan jika salah diberi nilai 0 kemudian diinterpretasikan sebagai berikut :
a) Baik : Nilai $=76-100 \%$
b) Cukup : Nilai $=56-75 \%$
c) Kurang : Nilai $=40-55 \%$
d) Tidak baik : Nilai $<40 \%$

2) Teknik Menyusui
a) Benar
Jika melakukan kedua teknik menyusui dengan benar
b) Salah
Jika hanya melakukan salah satu teknik menyusui dengan benar atau salah satunya

\section{b. Analisis bivariat}

Setelah data di kelompokkan sesuai dengan subvariabel yang diteliti. Instrumen yang telah diisi dilakukan pengolahan data dengan cara tabulasi silang dalam bentuk prosentase $(\%)$ dan untuk mengetahui hubungan pengetahuan ibu primipara dengan teknik menyusui yang benar di Desa Gayaman Kecamatan Mojoanyar Kabupaten Mojokerto menggunakan uji statistik chi square.

$$
\chi^{2}=\sum \frac{\left(f_{0}-f_{e}\right)^{2}}{f_{e}}
$$

Keterangan :

Fo : frekuensi observasi

Fe : frekuensi harapan

(Hidayat, $2007:$ 137)

Dengan hipotesis $\mathrm{H}_{0}$ ditolak bila $\mathrm{X}^{2}$ hit $\geq \mathrm{X}^{2}$ tab, berarti ada hubungan yang bermakna antara pengetahuan ibu primipara dengan teknik menyusui yang benar di Desa Gayaman Kecamatan Mojoanyar Kabupaten Mojokerto bila X²hit $\leq X^{2}$ tab. 
D. HASIL PENELITIAN.

1. Data Umum.

a. Karakteristik Responden Berdasarkan Umur.

Tabel 39. Karakteristik Responden Berdasarkan Umur di Desa Gayaman

Kecamatan Mojoanyar Kabupaten Mojokerto pada tanggal 16-17

Juli 2010.

\begin{tabular}{|c|l|c|c|}
\hline No. & \multicolumn{1}{|c|}{ Umur } & Frekuensi & Persentase (\%) \\
\hline 1. & $<20$ tahun & 11 & 36,7 \\
\hline 2. & $20-35$ tahun & 19 & 63,3 \\
\hline 3. & $>35$ tahun & 0 & 0 \\
\hline \multicolumn{2}{|c|}{ Total } & $\mathbf{3 0}$ & $\mathbf{1 0 0}$ \\
\hline
\end{tabular}

Berdasarkan tabel 39 diketahui bahwa lebih dari 50\% responden adalah berumur 20-35 tahun yaitu sebanyak 50 orang $(61,7 \%)$.

b. Karakteristik Responden Berdasarkan Pendidikan.

Tabel 40. Karakteristik Responden Berdasarkan Pendidikan di Desa Gayaman

Kecamatan Mojoanyar Kabupaten Mojokerto pada tanggal 16-17

Juli 2010.

\begin{tabular}{|c|l|c|c|}
\hline No. & \multicolumn{1}{|c|}{ Pendidikan } & Frekuensi & Persentase (\%) \\
\hline 1. & SD & 9 & 30 \\
\hline 2. & SMP & 9 & 30 \\
\hline 3. & SMA & 12 & 40 \\
\hline 4. & Perguruan Tinggi & 0 & 0 \\
\hline \multicolumn{2}{|c|}{ Total } & $\mathbf{3 0}$ & $\mathbf{1 0 0}$ \\
\hline
\end{tabular}

Berdasarkan tabel 40 diketahui bahwa paling banyak responden berpendidikan SMA yaitu sebanyak 12 orang $(75,3 \%)$.

c. Karakteristik Responden Berdasarkan Pekerjaan.

Tabel 41. Karakteristik Responden Berdasarkan Pekerjaan di Desa Gayaman Kecamatan Mojoanyar Kabupaten Mojokerto pada tanggal 16-17 Juli 2010.

\begin{tabular}{|c|l|c|c|}
\hline No. & \multicolumn{1}{|c|}{ Pekerjaan } & Frekuensi & Persentase (\%) \\
\hline 1. & Bekerja & 15 & 50 \\
\hline 2. & Tidak bekerja & 15 & 50 \\
\hline \multicolumn{2}{|c|}{ Total } & $\mathbf{3 0}$ & $\mathbf{1 0 0}$ \\
\hline
\end{tabular}

Berdasarkan tabel 41 menunjukkan bahwa hampir setengahnya responden

2. Data Khusus.

bekerja sebagai petani yaitu sebanyak 37 orang $(45,7 \%)$.

a. Karakteristik Responden Berdasarkan Pengetahuan.

Tabel 42. Karakteristik Responden Berdasarkan Pengetahuan di Desa Gayaman Kecamatan Mojoanyar Kabupaten Mojokerto pada tanggal 16-17 Juli 2010.

\begin{tabular}{|c|c|c|c|}
\hline No. & Pengetahuan & Frekuensi & Persentase (\%) \\
\hline 1. & Baik & 7 & 40 \\
\hline 2. & Cukup & 11 & 36,7 \\
\hline 3. & Kurang & 12 & 23,3 \\
\hline & Total & 30 & 100 \\
\hline
\end{tabular}

Berdasarkan tabel 42 menunjukkan bahwa paling banyak responden mempunyai pengetahuan kurang tentang teknik menyusui yang benar yaitu sebanyak 12 orang $(40 \%)$. 
b. Karakteristik Responden Berdasarkan Pelaksanaan Teknik Menyusui.

Tabel 43. Karakteristik Responden Berdasarkan Pelaksanaan Teknik Menyusui di Desa Gayaman Kecamatan Mojoanyar Kabupaten Mojokerto pada tanggal 16-17 Juli 2010.

\begin{tabular}{|c|c|c|c|}
\hline No. & Teknik Menyusui & Frekuensi & Persentase (\%) \\
\hline 1. & Salah & 14 & 46,7 \\
\hline 2. & Benar & 16 & 53,3 \\
\hline & Total & 30 & 100 \\
\hline
\end{tabular}

Berdasarkan tabel 43 menunjukkan bahwa lebih dari 50\% responden melakukan teknik menyusui dengan benar yaitu sebanyak 16 orang $(53,3 \%)$.

c. Analisa data hubungan antara pengetahuan ibu primipara dengan tehnik menyusui yang benar.

Tabel 44. Tabulasi Silang Antara Pengetahuan Ibu Primipara Dengan Tehnik Menyusui Yang Benar di Desa Gayaman Kecamatan Mojoanyar Kabupaten Mojokerto pada tanggal 16-17 Juli 2010.

\begin{tabular}{|c|c|c|c|c|c|c|c|c|c|}
\hline \multirow{3}{*}{ No. } & \multirow{3}{*}{$\begin{array}{c}\text { Tehnik } \\
\text { Menyusui }\end{array}$} & \multicolumn{6}{|c|}{ Pengetahuan } & \multirow{2}{*}{\multicolumn{2}{|c|}{ TOTAL }} \\
\hline & & \multicolumn{2}{|c|}{ Kurang } & \multicolumn{2}{|c|}{ Cukup } & \multicolumn{2}{|c|}{ Baik } & & \\
\hline & & $f$ & $(\%)$ & $f$ & $(\%)$ & $f$ & $(\%)$ & $f$ & $(\%)$ \\
\hline 1. & Benar & 3 & 10 & 7 & 23,3 & 6 & 20 & 16 & 53,3 \\
\hline 2. & Salah & 9 & 30 & 4 & 13,3 & 1 & 3,3 & 14 & 46,7 \\
\hline & Jumlah & 12 & 40 & 11 & 36,7 & 7 & 23,3 & 30 & 100 \\
\hline & & & $\begin{array}{l}\text { isig } \\
\text { kore }\end{array}$ & $\begin{array}{l}\text { aile } \\
\text { spe }\end{array}$ & $\begin{array}{l}=0,00 t \\
\text { han's } 1\end{array}$ & & & & \\
\hline
\end{tabular}

Berdasarkan Tabel 44 di atas dapat dilihat bahwa dari 30 responden dalam penelitian ini, paling banyak responden yang melakukan teknik menyusi dengan benar adalah responden berpengetahuan cukup yaitu sebanyak 7 responden $(23,3 \%)$. Sedangkan paling banyak responden yang melakukan teknik menyusui salah adalah responden berpengetahuan kurang yaitu sebanyak 9 responden (30\%).

Hasil Tabel tabulasi silang, selanjutnya dilakukan perhitungan spearman's rho dengan bantuan SPSS v16 for windows. Hasil uji spearman's rho derajat kemaknaan 0,05 didapatkan nilai signifikansi 0,006 , sehingga nilai $0,006<0,05$ yang berarti $\mathrm{H}_{0}$ ditolak dan ada hubungan antara pengetahuan ibu primipara dengan tehnik menyusui yang benar Di Desa Gayaman Kecamatan Mojoanyar Kabupaten Mojokerto. Untuk melihat seberapa erat hubungan tersebut dapat dilihat dari nilai korelasi spearman's rho sebesar 0,491, menurut Somantri (2006) nilai tersebut termasuk dalam kategori cukup erat.

\section{E. PEMBAHASAN.}

1. Pengetahuan ibu di Desa Gayaman Kecamatan Mojoanyar Kabupaten Mojokerto

Berdasarkan tabel 42 didapatkan data bahwa paling banyak responden mempunyai pengetahuan kurang tentang teknik menyusui yang benar yaitu sebanyak 12 orang (40\%). Fakta lain yang didapat dari penelitian berdasarkan kuesioner adalah paling banyak responden tidak dapat menjawab bahwa kepala bayi agak menengadah adalah teknik menyusui yang benar dan bagaimana cara perlekatan yang benar. Sedangkan paling banyak responden mengetahui bahwa menyusui adalah proses pemberian susu kepada bayi atau anak kecil dengan air susu ibu (ASI) dari payudara ibu.

Menurut Notoatmodjo (2003) pengetahuan adalah hasil "tahu" dan ini terjadi setelah orang melakukan pengindraan terhadap suatu objek tertentu. Pengindraan terjadi melalui panca indra manusia, yakni indra penglihatan, pendengaran, penciuman, rasa dan raba. Tingkat pengetahuan ibu tentang teknik menyusui nantinya akan diaplikasikan dalam penyusuan bayinya, aplikasi sendiri menurut Notoatmodjo (2003) diartikan sebagai kemampuan untuk menggunakan materi yang telah di pelajari pada situasi atau kondisi real ( sebenamya). Aplikasi 
di sini dapat di artikan sebagai aplikasi atau penggunaan hukum, rumus, metode, prinsip, dan sebagainya dalam konteks atau situasi yang lain.

Berdasarkan hasil penelitian didapatkan bahwa paling banyak responden mempunyai pengetahuan yang kurang tentang teknik menyusui yang benar, dapat mempengaruhi keberhasilan pemberian ASI. Perlu diketahui adalah bahwa pengetahuan seseorang tidak dapat terbentuk dengan sendirinya. Seseorang dapat memperoleh pengetahuan baik dengan cara kuno seperti coba-salah, otoriter, pengalaman pribadi ataupun jalan pikiran. Adapula yang memperoleh pengetahuan dengan cara modern seperti metode penelitian ilmiah dan lain-lain. Banyak faktor-faktor yang mempengaruhi terbentuknya pengetahuan seseorang dalam hal ini adalah pengetahuan tentang teknik menyusui yang benar.

Faktor utama yang dapat mempengaruhi pengetahuan seseorang adalah umur. Dari hasil penelitian didapatkan bahwa dari 30 responden penelitian, paling banyak responden yang mempunyai pengetahuan kurang adalalah responden berusia 20-35 tahun yaitu sebanyak 7 responden $(23,3 \%)$, dan paling sedikit responden yang berpengetahuan baik adalah responden yang berusia kurang dari 20 tahun yaitu sebanyak 1 responden $(3,3)$. Dari beberapa teori menyebutkan bahwa semakin cukup umur, tingkat kematangan dan kekuatan seseorang akan lebih matang dalam berpikir dan bekerja. Oleh karena itu banyaknya responden yang berpengatahuan kurang dikarenakan mereka belum matang dalam menerima informasi yang didapatkan terutama tentang teknik menyusui yang benar dan hal tersebut sangat mempengaruhi perilaku pemberian ASI pada bayi mereka nantinya.

Faktor pendidikan dapat mempengaruhi pengetahuan responden tentang teknik menyusui yang benar. Berdasarkan hasil tabulasi silang pengetahuan dengan pendidikan, paling banyak responden yang berpengetahuan baik adalah responden berpendidikan SMA yaitu sebanyak 7 responden $(23,3 \%)$ sedangkan responden yang berpendidikan SD tidak satupun yang berpengetahuan baik. Menurut Erfandi (2009) pengetahuan sangat erat kaitannya dengan pendidikan dimana diharapkan seseorang dengan pendidikan tinggi, maka orang tersebut akan semakin luas pula pengetahuannya. Namun perlu ditekankan bahwa seorang yang berpendidikan rendah tidak berarti mutlak berpengetahuan rendah pula. Peningkatan pengetahuan tidak mutlak diperoleh di pendidikan formal, akan tetapi juga dapat diperoleh pada pendidikan non formal. Namun perlu ditekankan bahwa seorang yang berpendidikan rendah tidak berarti mutlak berpengetahuan rendah pula. Peningkatan pengetahuan tidak mutlak diperoleh di pendidikan formal, akan tetapi juga dapat diperoleh pada pendidikan non formal. Tidak ada satupun responden yang berpendidikan SD berpengetahuan baik harus selalu dapat mengakses sumbersumber informasi tentang teknik menyusui yang benar terutama dari lingkungan sekitar (tetangga, keluarga, teman, dll) dan juga dari tenaga kesehatan supaya mereka dapat meningkatkan pengetahuan mereka.

Pekerjaan merupakan faktor yang dapat mempengaruhi pengetahuan responden tentang teknik menyusui yang benar. Dari hasil penelitian didapatkan bahwa dari 30 responden penelitian, paling banyak responden yang tidak bekerja mempunyai pengetahuan kurang tentang teknik menyusui yang benar yaitu sebanyak 8 responden $(26,7 \%)$. Pekerjaan sangat berhubungan dengan interaksi seseorang dengan orang lain di lingkungan pekerjaannya. Menurut Erfandi (2009) lingkungan adalah segala sesuatu yang ada di sekitar individu, baik lingkungan fisik, biologis, maupun sosial. Lingkungan berpengaruh terhadap proses masuknya pengetahuan ke dalam individu yang berada dalam lingkungan tersebut. Hal ini terjadi karena adanya interaksi timbal balik ataupun tidak yang akan direspon sebagai pengetahuan oleh setiap individu.

Banyaknya responden yang berinteraksi dengan seseorang di lingkungan pekerjaan dapat menambah banyaknya referensi tentang teknik menyusui yang benar dan hal tersebut akan dapat meningkatkan pengetahuannya, pekerjaan juga dapat menyediakan informasi lebih banyak dari berbagai media, seperti media cetak dan elektronik. Oleh karena itu responden yang bekerja cenderung mempunyai pengetahuan lebih baik tentang teknik menyusui yang benar.

2. Pelaksanaan teknik menyusui di Desa Gayaman Kecamatan Mojoanyar Kabupaten Mojokerto 
Berdasarkan tabel 43 di atas menunjukkan bahwa lebih dari $50 \%$ responden melakukan teknik menyusui dengan benar yaitu sebanyak 16 orang $(53,3 \%)$. Fakta lain yang didapat dari penelitian melalui observasi adalah kebanyakan ibu tidak tahu teknik perlekatan yang benar dan paling banyak ibu mengetahui teknik menyusui dengan rebahan.

Menyusui adalah proses pemberian susu kepada bayi atau anak kecil dengan air susu ibu (ASI) dari payudara ibu. Bayi menggunakan refleks menghisap untuk mendapatkan dan menelan susu (Wikipedia, 2010). Menurut Perinasia yang dikutip Creasoft (2008) terdapat berbagai macam posisi menyusui. Cara menyususi yang tergolong biasa dilakukan adalah dengan duduk, berdiri atau berbaring. Sedangkan langkah-langkah menyusui yang benar adalah Bayi diletakkan menghadap ke ibu dengan posisi sanggah seluruh tubuh bayi, jangan hanya leher dan bahunya saja, kepala dan tubuh bayi lurus, hadapkan bayi ke dada ibu, sehingga hidung bayi berhadapan dengan puting susu, dekatkan badan bayi ke badan ibu, menyetuh bibir bayi ke puting susunya dan menunggu sampai mulut bayi terbuka lebar.

Banyaknya responden yang melakukan teknik menyusui dengan benar dapat mempengaruhi keberhasilan pemberian ASI, namun responden yang melakukan teknik menyusui dengan salah juga masih banyak. Kebanyakan mereka tidak mengetahui posisi perlekatan payudara dengan mulut bayi dengan benar. Banyak faktor yang mempengaruhi teknik menyusui yang dilakukan oleh ibu primipara.

Berdasarkan tabulasi silang usia dengan teknik menyusui didapatkan paling banyak responden berusia 20-35 tahun melakukan teknik menyusui dengan benar. Menurut Erfandi (2009) semakin bertambah usia akan semakin berkembang pula daya tangkap dan pola pikirnya, sehingga pengetahuan yang diperolehnya semakin membaik. Walaupun responden merupakan ibu primipara namun pada rentang usia ini responden sudah matang dalam menerima dan menerapkan informasi yang telah diterimanya terutama pada penerapan teknik menyusui yang benar.

Faktor pendidikan juga berpengaruh terhadap penerapan teknik menyusui. Berdasarkan tabulasi silang paling banyak responden berpendidikan SMA melakukan teknik menyusui dengan benar yaitu sebanyak 9 responden (30\%). Menurut Meliono (2010) Pendidikan" adalah sebuah proses pengubahan sikap dan tata laku seseorang atau kelompok dan juga usaha mendewasakan manusia melalui upaya pengajaran dan pelatihan, maka jelas dapat kita kerucutkan sebuah visi pendidikan yaitu mencerdaskan manusia. Dengan pendidikan yang tinggi responden semakin dewasa untuk menerima dan menerapkan informasi yang didapatkan, dengan pengetahuan yang baik tentang teknik menyusui yang benar dan manfaatnya terhadap keberhasilan menyusui, maka mereka cenderung untuk patuh melakukan dari informasi yang telah diterimanya.

Faktor lain yang dapat mempengaruhi pelaksanaan teknik menyusui yang benar adalah pekerjaan. Berdasarkan hasil penelitian paling banyak responden yang tidak bekerja melakukan teknik menyusui yang salah yaitu sebanyak 10 responden (33,3\%). Banyaknya responden yang tidak bekerja menerapkan teknik menyusui yang salah sangat disayangkan karena mengingat waktu mereka yang banyak untuk melakukan penyusuan pada bayinya, dengan seringnya menyusui pada bayinya seharusnya pengalaman mereka lebih banyak dari ibu bekerja. Menurut Erfandi (2009) pengalaman sebagai sumber pengetahuan adalah suatu cara untuk memperoleh kebenaran pengetahuan dengan cara mengulang kembali pengetahuan yang diperoleh dalam memecahkan masalah yang dihadapi masa lalu. Hasil penelitian tersebut mungkin tidak sesuai dengan teori yang ada namun perlu ditekankan ibu yang bekerja pun dapat melakukan teknik menyusui yang benar walaupun waktu mereka terbatas untuk menyusui bayinya, hal tersebut banyak diakibatkan mereka mengerti akan pentingnya ASI sehingga mereka selalu berusaha untuk menyusui bayinya dengan teknik yang benar.

3. Hubungan antara pengetahuan ibu primipara dengan tehnik menyusui yang benar Di Desa Gayaman Kecamatan Mojoanyar Kabupaten Mojokerto

Berdasarkan analisa data pada tabel 44 didapatkan dari 30 responden dalam penelitian ini, paling banyak responden yang melakukan teknik menyusi dengan benar adalah responden berpengetahuan cukup yaitu sebanyak 7 responden (23,3\%). Sedangkan paling banyak 
responden yang melakukan teknik menyusui salah adalah responden berpengetahuan kurang yaitu sebanyak 9 responden (30\%).

Hasil Tabel tabulasi silang, selanjutnya dilakukan perhitungan spearman's rho dengan bantuan SPSS v16 for windows. Hasil uji spearman's rho derajat kemaknaan 0,05 didapatkan nilai signifikansi 0,006 , sehingga nilai $0,006<0,05$ yang berarti $\mathrm{H}_{0}$ ditolak dan ada hubungan antara pengetahuan ibu primipara dengan tehnik menyusui yang benar Di Desa Gayaman Kecamatan Mojoanyar Kabupaten Mojokerto. Untuk melihat seberapa erat hubungan tersebut dapat dilihat dari nilai korelasi spearman's rho sebesar 0,491, menurut Somantri (2006) nilai tersebut termasuk dalam kategori cukup erat.

Menurut Nikilah (2009) primipara adalah wanita yang telah melahirkan bayi yang viabel untuk pertama kalinya. Kemampuan primipara untuk melakukan penyusuan dengan benar berhubungan dengan pengalaman dan pengetahuan. Menurut Erfandi (2009) Pengalaman sebagai sumber pengetahuan adalah suatu cara untuk memperoleh kebenaran pengetahuan dengan cara mengulang kembali pengetahuan yang diperoleh dalam memecahkan masalah yang dihadapi masa lalu. Pengalaman belajar yang dikembangkan memberikan pengetahuan dan keterampilan serta pengalaman belajar selama bekerja akan dapat mengembangkan kemampuan mengambil keputusan yang merupakan manifestasi dari keterpaduan menalar secara ilmiah dan etik yang bertolak dari masalah nyata dalam apa yang akan dilakukannya.

Sedangkan menurut Perinasia (2008) teknik menyusui yang benar dapat memberikan efek antara lain bayi tampak tenang, badan bayi menempel pada perut ibu, mulut bayi terbuka lebar, dagu bayi menempel pada payudara ibu, sebagian areola masuk kedalam mulut bayi, areola bawah lebih banyak yang masuk, bayi nampak menghisap kuat dengan irama perlahan, puting susu tidak terasa nyeri, telinga dan lengan bayi terletak pada satu garis lurus, kepala bayi agak menengadah.

Terdapatnya hubungan antara pengetahuan ibu primipara dengan tehnik menyusui yang benar menegaskan bahwa pengetahuan teknik menyusui yang benar harus diketahui oleh ibu menyusui khususnya ibu primipara. Karena dengan keberhasilan menyusui dengan teknik yang benar maka bayi akan mendapatkan nutrisi yang cukup yang terkandung dalam ASI. Selain itu terdapat juga kebanggaan dalam diri si ibu bahwa dia juga mampu memberikan ASI pada bayinya secara lancar, selain itu dampak lain seperti dampak ekonomi dimana ibu tidak harus mengeluarkan uang untuk membeli susu.

Masih terdapatnya responden yang berpengetahuan baik namun masih salah menerapkan teknik menyusui, dikarenakan ibu tersebut masih ragu untuk bisa menyusui bayinya dengan benar mengingat ibu tersebut adalah ibu primipara yang baru pertama kali melakukan penyusuan terhadap bayinya.

Peran tenaga kesehatan sangat penting untuk dapat meningkatkan pengetahuan dan juga penerapan teknik menyusui yang benar, seperti dengan mengadakan program penyuluhan tentang cara melakukan teknik menyusui yang benar ataupun dengan kunjungan rumah untuk memantau pemberian ASI yang dilakukan oleh ibu menyusui khususnya ibu primipara.

\section{F. PENUTUP.}

Hasil penelitian menunjukkan bahwa paling banyak responden mempunyai pengetahuan kurang tentang teknik menyusui yang benar yaitu sebanyak 12 orang (40\%). Lebih dari $50 \%$ responden melakukan teknik menyusui dengan benar yaitu sebanyak 16 orang $(53,3 \%)$. Hasil uji spearman's rho derajat kemaknaan 0,05 didapatkan nilai signifikansi 0,006 , sehingga nilai $0,006<0,05$ yang berarti $\mathrm{H} 0$ ditolak dan ada hubungan antara pengetahuan ibu primipara dengan teknik menyusui yang benar Di Desa Gayaman Kecamatan Mojoanyar Kabupaten Mojokerto

Bagi masyarakat khususnya ibu-ibu yang mempunyai bayi, walaupun masih merupakan pengalaman pertama menyusui namun harus selalu mencari informasi tentang teknik menyusui yang benar baik itu melalui tenaga kesehatan atau lingkungan sekitar. Dan terutama bagi kader untuk turut serta berperan aktif dalam rangka meningkatkan pengetahuan ibu tentang teknik 
menyusui yang benar melalui bimbingan atau penyuluhan pada pertemuan rutin dan pengajian ibu-ibu secara rutin dan berkala.

DAFTAR PUSTAKA.

Arief, B. (2009). Faktor-Faktor Yang Mempengaruhi Ibu Menyusui Yang Mengalami Putting Susu Lecet Pada Saat Awal Laktasi. http:/lebdosama.blogspot.com, diakses tanggal 30 April 2010).

Arikunto, Suharsimi. (2006). Prosedur Penelitian Suatu Pendekatan Praktik. Jakarta : Rineka Cipta. Budiarto, Eko. (2002). Biostatistika Untuk Kedokteran Dan Kesehatan Masyarakat. Jakarta : EGC.

Creasoft. (2008). Teknik Menyusui yang benar. http://creasoft.wordpress.com/, diakses tanggal 3 Mei 2010).

Erfandi, Prohealth. (2009). Pengetahuan Dan Faktor-Faktor Yang Mempengaruhi, diakses tanggal 28 April 2010

Hidayat, A.A. (2007). Riset Keperawatan Dan Teknik Penulisan Ilmiah. Jakarta : Salemba Medika.

Hidayat, A.A. (2009). Metode Penelitian Kebidanan Dan Teknik Analisa Data. Jakarta : Salemba Medika.

Hidayat, A.A. (2009). Metode Penelitian Keperawatan Dan Teknik Analisa Data. Jakarta : Salemba Medika.

Marimbi. Hanum. (2010). Tumbuh Kembang, Status Gizi Dan Imunisasi Dasar Balita. Yogyakarta : Nuha Medika.

Notoatmodjo, Soekidjo. (2003). Ilmu Kesehatan Masyarakat. Jakarta : Rineka Cipta.

Nursalam. (2008). Konsep Dan Penerapan Metodologi Penelitian Ilmu Keperawatan. Jakarta : Salemba Medika.

Pratomo. Budiman. (2005). Manajemen Pengetahuan. (ttp://Arfandi0900.Blog.Binusian.Org. diakses tanggal 28 April 2010).

Roesli, Utami. (2000). Menyusui. http://tutorialkuliah.blogspot.com, diakses tanggal 25 April 2010).

Somantri, 2006. Aplikasi Statistika Dalam Penelitian. Bandung : Pustaka Setia.

Sugianto. (2008). Menyusui, langkah Perlindungan, http://sentralaktasiindonesia.wordpress.com. diakses tanggal 30 April 2010).

Sugiyono. (2009). Statistika Untuk Penelitian. Jakarta : Alfabeta.

Surjadi, Pratiwi. (2008). Mungkinkah ASI Kurang. http://corpusalienum.multiply.com, diakses tanggal 25 April 2010).

Wikipedia Indonesia. (2010). Pengetahuan. (ttp://Id.Wikipedia.com, diakses tanggal 25 April 2010). 